\title{
PENERAPAN MODEL PEMBELAJARAN KOPERATIF TIPE STAD BERBANTUAN MEDIA KANTONG BILANGAN DALAM MENINGKATKAN HASIL BELAJAR MATEMATIKA
}

\author{
Hardianto $^{1}$, Islah ${ }^{2}$, Marissa Ulfa ${ }^{3}$, Kiki Fauziah ${ }^{4}$ \\ Universitas Cokroaminoto Palopo ${ }^{1,2,3,4}$ \\ hardiantomath9@uncp.ac.id ${ }^{1}$
}

\begin{abstract}
Abstrak. Penelitian ini dilatarbelakangi oleh rendahnya hasil belajar matematika. Penelitian ini bertujuan untuk mengetahui: penerapan model pembelajaran kooperatif tipe STAD berbantuan media kantong bilangan efektif terhadap hasil belajar matematika. Jenis penelitian ini adalah penelitian tindakan kelas. Model penelitian yang digunakan adalah Kemmis dan Taggart dengan menggunakan dua siklus. Setiap siklus dilaksanakan dalam enam kali pertemuan. Subjek penelitian ini adalah 26 siswa kelas III SDN 96 Campurejo yang terdiri dari 15 siswa lakilaki dan 11 siswa perempuan. Objek penelitian ini adalah penerapan model pembelajaran kooperatif tipe STAD berbantuan media kantong bilangan untuk meningkatan hasil belajar siswa. Metode pengumpulan data dilakukan melalui tes essay, observasi aktivitas siswa dan observasi aktivitas guru, dan dokumentasi. Teknik analisis data dilakukan secara kualitatif dan kuantitatif. Secara kualitatif melalui persentase hasil kinerja guru dan secara kuantitatif melalui nilai ketuntasan belajar siswa individual, nilai rata-rata hasil belajar siswa, persentase hasil belajar klasikal siswa. Indikator keberhasilan siswa ditandai dengan meningkatnya hasil belajar siswa dengan ketuntasan klasikal belajar siswa mencapai 70\%. Hasil penelitian menunjukkan bahwa terdapat peningkatan hasil belajar siswa. Peningkatan hasil belajar siswa kelas III dapat dilihat berdasarkan persentase yang meningkat dari pra tindakan siswa sebesar $23,0 \%$ mengalami peningkatan $30,8 \%$ pada siklus I menjadi $53,8 \%$ pada siklus II meningkat $34,6 \%$ menjadi $88,4 \%$.
\end{abstract}

\section{Kata kunci: Kooperatif tipe STAD, Media kantong bilangan, Hasil belajar Matematika.}

\begin{abstract}
This research is motivated by the low learning outcomes of mathematics. This study aims to determine: the application of the cooperative learning model type STAD assisted by pocket number media is effective on mathematics learning outcomes. This type of research is classroom action research. The research model used was Kemmis and Taggart using two cycles. Each cycle is carried out in six meetings. The subjects of this study were 26 grade III students of SDN 96 Campurejo consisting of 15 male students and 11 female students. The object of this research is the application of the cooperative learning model type STAD assisted by number bag media to improve student learning outcomes. Methods of data collection are done through essay tests, observation of student activities and observation of teacher activities, and documentation. The data were analyzed qualitatively and quantitatively. Qualitatively through the percentage of teacher performance results and quantitatively through the value of individual student learning completeness, the average value of student learning outcomes, the percentage of student classical learning outcomes. Indicators of student success are marked by the increase in student learning outcomes with classical learning completeness of students reaching $70 \%$. The results showed that there was an increase in student learning outcomes. The increase in student learning outcomes in class III can be seen based on the increased percentage from the pre-action of students by $23.0 \%$, an increase of $30.8 \%$ in the first cycle to $53.8 \%$ in the second cycle, an increase of $34.6 \%$ to $88.4 \%$.
\end{abstract}

Keywords: Cooperative type STAD, Number bag media, Mathematics learning outcomes.

\section{A. Pendahuluan}

Matematika adalah pengetahuan yang sangat terstruktur. Satu bagian tidak dapat terlepas dari bagian lainnya. Sebuah topik matematika yang telah dipelajari siswa tidak berdiri sendiri, 
tetapi terkait dengan topik matematika yang mendahuluinya. Seandainya siswa tidak menguasai topik yang pertama, siswa akan mengalami kesulitan belajar topik yang kedua dan seterusnya (Runtukahu, 2014). Matematika merupakan salah satu bidang studi yang menduduki peranan penting dalam pendidikan dan kehidupan masyarakat. Matematika adalah salah satu pengetahuan tertua dan dianggap sebagai induk atau alat dan bahasa dasar banyak ilmu.

STAD merupakan salah satu strategi pembelajaran kooperatif yang di dalamnya beberapa kelompok kecil siswa dengan level kemampuan akademik yang berbeda-beda saling bekerja sama untuk menyelesaikan tujuan pembelajaran. Tidak hanya secara akademik, siswa juga di kelompokkan secara beragam berdasarkan gender, ras, dan etnis (Rusman, 2012). STAD merupakan salah satu model pembelajaran kooperatif yang memicu siswa bekerja sama untukbelajar agar mereka saling mendorong dan membantu satu sama lain dalam menguasai kompetensi yang diharapkan serta menumbuhkan kesadaran bahwa belajar itu penting, bermakna dan menyenangkan. Model ini juga sangat mudah diadaptasi, telah digunakan dalam Matematika, IPA, IPS, Bahasa Inggris, teknik dan banyak subjek lainnya pada tingkat sekolah dasar sampai perguruan tinggi.

Media adalah perantara atau pengantar terjadinya komunikasi dari pengirim menuju penerima (Qomariyah, 2019). Media adalah alat bantu proses belajar mengajar. Dengan adanya media kantong bilangan dapat memudahkan guru dalam menyampaikan materi sehingga terjadi hubungan timbal balik antara guru dengan siswa. Siswa menjadi lebih aktif, tertarik untuk belajar dan dapat meningkatkan motivasi serta hasil belajar siswa. Kantong bilangan yang digunakan terbuat dari karton yang tebal atau dibuat dari kain, kantong-kantong yang dibuat kira-kira muat sedotan, kantong tersebut dibuat sama besar ditempel pada posisi barisan pertama secara horizontal. Bagian atas barisan pertama sebanyak tiga kantong dan dibawahnya barisan kedua sebanyak tiga kantong juga. Kemudian diberi tanda garis tebal secara mendatar dan juga ditulis tanda operasi penjumlahan. Kantong barisan ketiga horizontal dibuat dibawah garis tersebut. Masing-masing kantong dikondisikan agar dapat diletakkan sedotan dan tinggi kantong kira-kira 2/3 sedotan.

Observasi awal dilakukan disalah satu sekolah dasar terdapat beberapa masalah secara umum yaitu rendahnya aktivitas dan hasil belajar siswa pada mata pelajaran Matematika, pendekatan yang digunakan guru bersifat monoton sehingga menyebabkan siswa cepat bosan, guru menjelaskan materi pembelajaran tanpa adanya bantuan media/alat peraga, serta kurang adanya interaksi antara guru dan siswa, maupun siswa dengan siswa.

Berdasarkan uraian di atas, maka dilaksanakan Penelitan Tindakan Kelas (PTK) yang berjudul "Penerapan Model Pembelajaran Kooperatif Tipe STAD Berbantuan Media Kantong Bilangan dalam Meningkatkan Hasil Belajar Matematika".

\section{B. Metode Penelitian}

Penelitian ini dilaksanakan pada tanggal 10 Februari- 9 Maret 2020 dan dilakukan pada kelas III SDN 96 Campurejo, Kecamatan Walenrang, Kabupaten Luwu. Jenis penelitian ini merupakan Penelitian Tindakan Kelas (PTK). Desain penelitian ini menurut Kemmis dan MC Tanggart, sebagai berikut: 


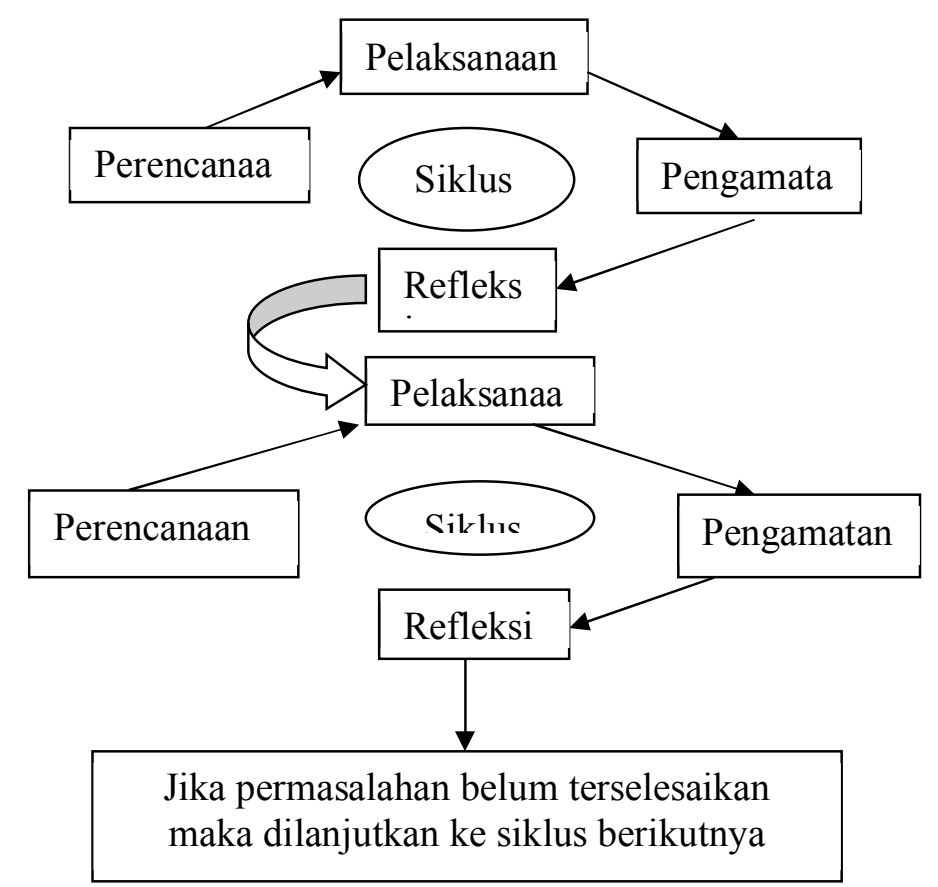

Gambar 2. Desain PTK menurut Kemmis dan MC Tanggart

Teknik Pengumpulan Data: 1) Observasi: Penilaian pelaksanaan proses pembelajaran dikelas. penilaian ini dilakukan guru terhadappelaksanaan pembelajaran yang dilakukan olehpeneliti. Penilaian pembelajaran di berikan dalam bentuk lembar observasi centang atau ceklis. Observasi ini terdiri dari 2 macam yaitu observasi aktivitas guru dan observasi aktivitas siswa, 2) Tes: Pengumpulan data dengan teknik tes untuk mengungkapkan keberhasilan hasil belajar siswa dengan penerapan model kooperatif tipe STAD berbantuan media kantong bilangan dalam pelajaran Matematika. Soal yang digunakan untuk mengetahui ketercapaian tujuan perbaikan. Tes soal berupa essay yang terdiri dari 5 nomor soal. Jenis tes ini digunakan pada lembar kerja siswa dan kuis, dan, 3) Dokumentasi dalam penelitian ini adalah mengumpulkan data berupa foto dan video.

Teknik Analisis Data: 1) Analisis data kuantitatif: Peneliti menggunakan analisis data kuantitatif, analisis data ini digunakan untuk menentukan peningkatan hasil belajar siswa melalui tindakan dari setiap siklus yang dilakukan guru. Tujuan analisis data dalam penelitian tindakan ini adalah untuk memperoleh data apakah terjadi perbaikan dan peningkatan sebagaimana yang diharapkan. Analisis data kuantitatif dalam penelitian ini adalah analisis lembar observasi aktivitas siswa dan hasil tes. Tes individu yang dilakukan untuk mengukur kemampuan siswa dalam pembelajaran Matematika menggunakan soal uraian.

Analisis data hasil observasi dan tes ini bertujuan untuk mengetahui peningkatan hasil belajar Matematika siswa kelas III melalui model pembelajaran kooperatif tipe STAD berbantuan media kantong bilangan. Nilai atau poin dari lembar observasi dan tes evaluasi akan dibandingkan antara siklus 1 dan siklus 2, apabila mengalami peningkatan maka dapat diasumsikan bahwa hasill belajar siswa meningkat menggunakan model pembelajaran kooperatif tipe STAD berbantuan media kantong bilangan dan efektif diterapkan di kelas III.

\section{a. Nilai ketuntasan belajar siswa individual}

$$
\text { Nilai }=\frac{\text { Skor yang diperoleh }}{\text { Skor maksimum }} \times 100
$$


Tabel 2. Kriteria keberhasilan

\begin{tabular}{lll}
\hline No. & Tingkat keberhasilan & Keterangan \\
\hline 1 & $0-45$ & Kurang \\
2 & $46-60$ & Cukup \\
3 & $61-75$ & Baik \\
4 & $76-100$ & Sangat baik \\
\hline
\end{tabular}

Sumber: (Purwanto, 2011)

b. Nilai rata-rata hasil belajar siswa

$$
\begin{aligned}
& \mathrm{X}=\frac{E X}{E N} \\
& \text { Dimana : } \quad X=\text { Nilai rata-rata } \\
& \mathrm{EX}=\text { Jumlah semua nilai siswa } \\
& \mathrm{EN}=\text { Jumlah siswa }
\end{aligned}
$$

Tabel 3. Nilai rata-rata siswa

\begin{tabular}{lll}
\hline No. & Tingkat keberhasilan & Keterangan \\
\hline 1 & $0-54$ & Sangat rendah \\
2 & $55-64$ & Rendah \\
3 & $65-79$ & Sedang \\
4 & $80-89$ & Tinggi \\
5 & $90-100$ & Sangat tinggi \\
\hline
\end{tabular}

Sumber: (Agung, 2010)

c. Persentase hasil belajar klasikal siswa

$$
\mathrm{P}=\mathrm{F} / \mathrm{N} \times 100 \%
$$

Dimana : $\mathrm{P}=$ Angka prestasi

$\mathrm{F} \quad=$ Jumlah siswa yang mengalami perubahan

$\mathrm{N} \quad=$ Jumlah seluruh siswa

Tabel 4. Persentase hasil belajar klasikal

\begin{tabular}{lcl}
\hline No. & Tingkat keberhasilan & Kategori \\
\hline 1 & $\geq 80$ & Sangat baik \\
2 & $66-80$ & Baik \\
3 & $46-65$ & Cukup \\
4 & $\leq 45$ & Kurang \\
\hline
\end{tabular}

Sumber: (Purwanto, 2011)

\section{d. Analisis data kualitatif}

$$
\mathrm{N}=\frac{\text { Skor yang diperoleh }}{\text { Skor maksimum }} \times 100
$$

Tabel 5. Kategori skor dan persentase kinerja guru

\begin{tabular}{lcl}
\hline Skor & Tingkat keberhasilan & Kategori \\
\hline 5 & $\geq 81$ & Sangat baik \\
4 & $66-80$ & Baik \\
3 & $50-65$ & Cukup baik \\
2 & $20-49$ & Kurang baik \\
1 & $\leq 20$ & Sangat kurang \\
\hline
\end{tabular}

Sumber: (Arikunto, 2016) 
Indikator Keberhasilan Keberhasilan penelitian ini dalam penerapan model pembelajaran kooperatif tipe STAD berbantuan media kantong bilangan dapat dilihat pada indikator: 1) Terjadi peningkatan hasil belajar siswa di kelas III pada siklus I dan siklus II, 2) Hasil belajar siswa meningkat apabila penerapan model pembelajaran kooperatif tipe STAD berbantuan media kantong bilangan efektif diterapkan, dan 3) Pada akhir penelitian, perhitungan persentase nilai hasil belajar klasikal siswa mencapai $\geq 70 \%$ atau siswa memperoleh nilai $\geq 70$ sesuai dengan KKM yang telah ditentukan oleh sekolah.

\section{Hasil Penelitian}

1) Pra Penelitian Berdasarkan hasil wawancara dengan guru kelas, hasil belajar matematika siswa dianggap masih rendah dan harus ada perbaikan tindakan selanjutnya. Nilai hasil belajar siswa dapat dilihat:

Tabel 6. Nilai hasil belajar siswa (Pra Penelitian)

\begin{tabular}{llllll}
\hline Kelas & Nilai rata-rata & Siswa yang mencapai KKM & $\begin{array}{l}\text { Siswa yang } \\
\text { KKM }\end{array}$ & belum mencapai \\
\cline { 2 - 6 } & & Jumlah & Persentase & Jumlah & Persentase \\
\hline III & 65,1 & 6 & $23,0 \%$ & 20 & $76,9 \%$ \\
\hline
\end{tabular}

Berdasarkan tabel 6 di atas, nilai hasil belajar pra penelitian kelas III SDN 96 Campurejo dapat diketahui bahwa sebanyak 6 siswa dengan persentase 23,0 \% siswa yang mencapai KKM. Sedangkan 20 siswa dengan persentase 76,9 \% siswa yang belum mencapai KKM. Pada tahap pra penelitian ini, nilai rata-rata siswa sebesar 65,1 . Hasil belajar pra penelitian ini dimasukkan pada gambar 3 berikut.

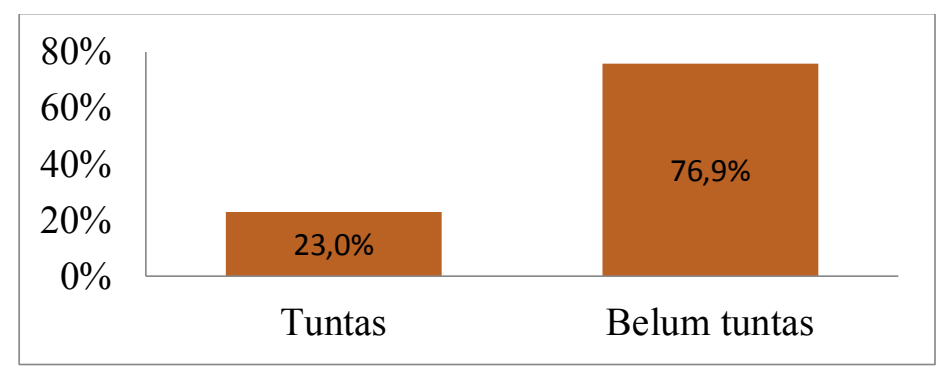

Gambar 3. Persentase hasil belajar siswa (Pra Penelitian)

Dari gambar 3 di atas, hasil belajar siswa (pra penelitian) dapat disimpulkan berikut ini: 1) Pada tahap pra penelitian hanya 6 siswa yang mencapai $K K M$ hasil belajar $\geq 70$, Sedangkan 20 siswa lainnya belum mencapai KKM, 2) Persentase siswa yang mencapai KKM sebesar 23,0 $\%$, sedangkan persentase siswa yang belum mencapai KKM sebesar 76,9\%, dan 3) Nilai ratarata siswa 65,1 .

Siklus 1: 1) Perencanaan siklus 1 dilaksanakan mulai tanggal 10 Februari 2020. Dalam perencanaan tindakan ini peneliti sebagai pengamat sekaligus sebagai guru mengajar. Perencanaannya sebagai berikut: 1) Menentukan materi yang akan dibahas, 2) Menyusun Rencana Pelaksanaan Pembelajaran (RPP) dengan model pembelajaran kooperatif tipe STAD berbantuan media kantong bilangan, 3) Membuat lembar kerja siswa, 4) Membuat lembar observasi guru dan lembar observasi siswa, dan 5) Membuat media kantong bilangan yang digunakan pada saat mengajar.

2) Pelaksanaan Proses pembelajaran pada siklus I ini akan dilaksanakan 6 pertemuan dengan menggunakan model pembelajaran kooperatif tipe STAD berbanntuan media kantong bilangan. Berdasarkan penelitian pada pertemuan satu hingga pertemuan enam, hasil belajar 
matematika siswa pada siklus I ini diperoleh nilai rata-rata sebesar 71,1. Sebanyak 14 siswa dengan persentase 53,8 \% siswa yang mencapai KKM. Sedangkan sebanyak 12 siswa dengan persentase 46,1 \% siswa yang belum mencapai KKM. Hasil belajar siswa siklus I ini dapat dilihat pada tabel 7 berikut ini.

Tabel 7. Hasil belajar siswa siklus 1

\begin{tabular}{llllll}
\hline Kelas & Nila rata-rata & Siswa yang mencapai KKM & $\begin{array}{l}\text { Siswa } \\
\text { KKM }\end{array}$ & yang belum mencapai \\
\cline { 2 - 6 } & & Jumlah & Persentase & Jumlah & Persentase \\
\hline III & 71,1 & 14 & $53,8 \%$ & 12 & $46,1 \%$ \\
\hline
\end{tabular}

Dari tabel 7 di atas, hasil rata-rata belajar siswa kelas III adalah 71,1 dengan kategori (Sedang) serta 53,8 \% siswa sudah mencapai KKM. Sedangkan 46,1 \% siswa yang belum mencapai KKM. Hal ini menunjukkan bahwa nilai rata-rata siswa sudah tercapai dari indikator keberhasilan $\geq 70$, namun ketuntasan belajar klasikal siswa belum tercapai dan meningkat sesuai dengan indikator keberhasilan. Hasil belajar siswa siklus I dapat di masukkan pada gambar 4 berikut.

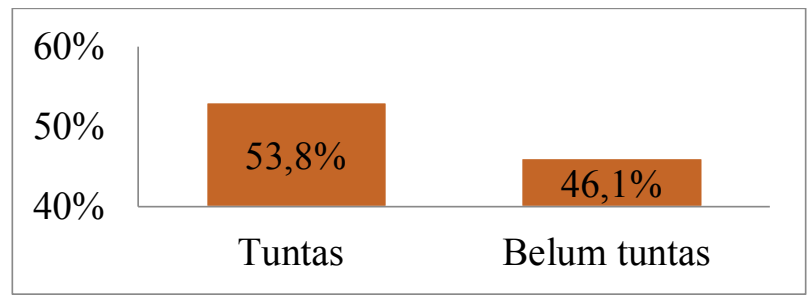

Gambar 4. Persentase hasil belajar siswa siklus I

Dari gambar 4 di atas, hasil belajar siswa siklus I dapat disimpulkan berikut ini: 1) Pada siklus I sebanyak 14 siswa yang mencapai KKM hasil belajar $\geq 70$, sedangkan 12 siswa lainnya belum mencapai KKM, 2) Persentase siswa yang mencapai KKM sebesar 53,8 \%, sedangkan persentase siswa yang belum mencapai KKM sebesar 46,1, dan 3) Nilai rata-rata siswa 71,1.

4) Refleksi siklus I 1) Siswa kurang kompak dalam kelompoknya masing-masing, 2) Siswa terlihat kebingungan dalam mengerjakan LKS, 3) Siswa kurang membaur dengan teman kelompoknya dan kurang bekerja sama, 4) Siswa susah diatur saat pembagian kelompok karena merasa dirinya tidak pintar dan hanya mau duduk berkelompok dengan temannya yang pintar, dan 5) Siswa masih dibantu oleh guru dalam menyelesaikan kuis.

Berdasarkan beberapa hambatan pada siklus I ini, maka didapatkan solusi: 1) Guru menekankan bahwa kekompakan dalam berkelompok itu sangat penting, dengan saling membantu satu sama lain dalam menyelesaikan soal atau tugas yang diberikan oleh ibu guru, 2) Pada saat siswa kebingungan dalam mengerjakan LKS, guru membimbing siswa secara perlahan-lahan terkait penjelasan yang ada pada LKS dan menjelaskan contoh konkritnya yang mudah dipahami oleh siswa, 3) Guru memberikan bimbingan jika dalam situasi seperti ini mengerjakan soal dengan berkelompok harus saling membantu dan bekerja sama dalam menyelesaikan soalnya, harus kompak dan tidak boleh egois. Jika semuanya berkerja sama dan saling membantu dalam satu kelompok pasti soalnya akan mudah dikerjakan dan akan cepat selesai, 4) Guru memantau setiap kelompok agar setiap kelompok dapat berpartisipasi atau saling bekerja sama dalam diskusi kelompok, dan 5) Guru menjelaskan ulang secara perlahanlahan cara mengerjakan kuis menggunakan media kantong bilangan dengan contoh-contoh yang mudah dipahami siswa.

Siklus 2: 1) Perencanaan Perencanaan siklus II ini tidak jauh berbeda dengan siklus I yaitu menyusun Rencana Pelaksanaan Pembelajaran (RPP) yang menggunakan model pembelajaran 
kooperatif STAD berbantuan media kantong bilangan, membuat lembar kerja siswa yang baru, membuat lembar observasi aktivitas guru dan lembar observasi aktivitas siswa, dan membuat media kantong bilangan yang baru agar membuat siswa lebih tertarik dalam mengikuti pembelajaran.

2) Pelaksanaan Berdasarkan penelitian pada pertemuan tujuh hingga pertemuan duabelas, hasil belajar matematika siswa pada siklus II ini diperoleh nilai rata-rata sebesar 96,5. Sebanyak 23 siswa dengan persentase 88,4 \% siswa yang mencapai KKM. Sedangkan sebanyak 3 siswa dengan persentase $11,5 \%$ siswa yang belum mencapai KKM. Hasil belajar siswa siklus II ini dapat dilihat pada tabel 12 berikut ini:

Tabel 12. Hasil belajar siswa siklus II

\begin{tabular}{llllll}
\hline Kelas & Nilai rata-rata & \multicolumn{2}{l}{ Siswa yang mencapai KKM } & \multicolumn{2}{l}{$\begin{array}{l}\text { Siswa yang belum mencapai } \\
\text { KKM }\end{array}$} \\
\cline { 2 - 6 } & & Jumlah & Persentase & Jumlah & Persentase \\
\hline III & 96,5 & 23 & $88,4 \%$ & 3 & $11,5 \%$ \\
\hline
\end{tabular}

Dari tabel 12 di atas, hasil rata-rata belajar siswa kelas III adalah 96,5 dengan kategori (Sangat Tinggi) serta 88,4 \% siswa sudah mencapai KKM. Sedangkan 11,5\% siswa yang belum mencapai KKM. Hasil belajar siswa siklus II dapat dimasukkan pada gambar 5 berikut.

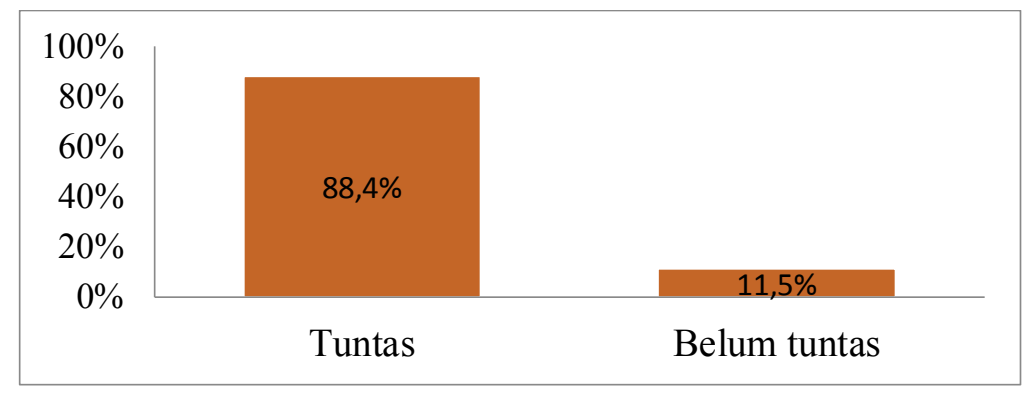

Gambar 5. Persentase hasil belajar siswa siklus II

Dari gambar 5 di atas, hasil belajar siswa siklus II dapat di simpulkan berikut ini: 1) Pada siklus II sebanyak 23 siswa yang mencapai KKM hasil belajar $\geq 70$, sedangkan 3 siswa lainnya belum mencapai nilai KKM, 2) Persentase siswa yang mencapai KKM sebesar 88,4 \%, sedangkan persentase siswa yang belum mencapai KKM sebesar 11,5\%, dan 3) Nilai rata-rata siswa 96,5 .

Kemudian perbandingan nilai hasil belajar siswa dari pra penelitian, siklus I dan siklus II dapat di lihat pada tabel 13 sebagai berikut.

Tabel 13. Perbandingan hasil belajar siswa pra penelitian, siklus I, dan siklus II

\begin{tabular}{llll}
\hline Kategori & $\begin{array}{l}\text { Pra } \\
\text { Penelitian }\end{array}$ & Siklus I & Siklus II \\
\hline Siswa yang tuntas & 6 & 14 & 23 \\
\hline Siswa yang tidak tuntas & 20 & 12 & 3 \\
\hline Ketuntasan belajar klasikal & $23,0 \%$ & $53,8 \%$ & $88,4 \%$ \\
\hline
\end{tabular}

Dari tabel 13 di atas, nilai hasil belajar siswa kelas III dari pra penelitian, siklus I, dan siklus II adalah siswa yang tuntas pada pra penelitian hanya 6 siswa, di siklus I terdapat peningkatan dengan 14 siswa, sedangkan pada siklus II terdapat 23 siswa yang sudah tuntas. Sedangkan pada kategori siswa yang belum tuntas pada pra penelitian terdapat 20 siswa, di 
siklus I mulai menurun dengan 12 siswa, pada siklus II hanya 3 siswa saja yang belum tuntas dalam penelitian ini.

Ketuntasan klasikal hasil belajar siswa di kelas III SDN 96 Campurejo tercapai dengan baik sebagaimana yang terlihat pada tabel bahwa pada pra penelitian $23,0 \%$, di siklus I meningkat yaitu 53,8\%. Sedangkan pada siklus II ketuntasan belajar klasikal siswa sebesarr $88,4 \%$. Perbandingan ketuntasan belajar klasikal siswa pada pra siklus, siklus I, dan siklus II dapat dimasukkan dalam gambar 6 berikut.

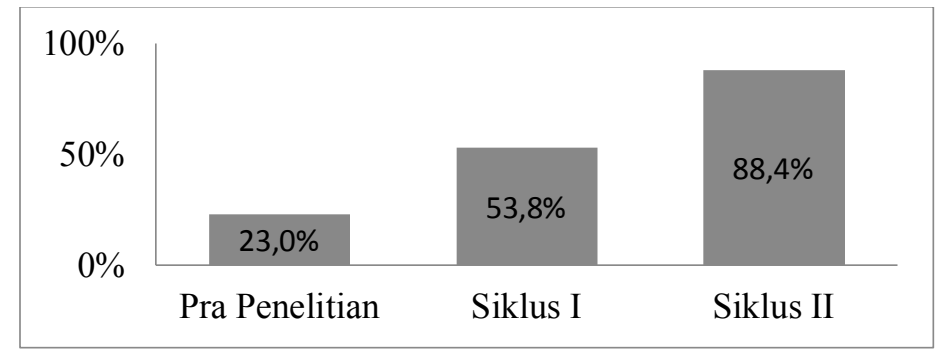

Gambar 6. Persentase klasikal hasil belajar siswa

Kemudian perbandingan nilai rata-rata siswa dari pra penelitian, siklus I dan siklus II dapat di lihat pada tabel 14dan diagram 7 berikut ini.

Tabel 14. Perbandingan nilai rata-rata siswa

\begin{tabular}{|c|c|c|c|c|}
\hline Jumlah siswa & \multicolumn{4}{|c|}{ Rata-rata hasil belajar } \\
\hline \multirow[t]{6}{*}{26} & \multicolumn{2}{|c|}{ Pra Penelitian } & Siklus I & Siklus II \\
\hline & \multicolumn{2}{|c|}{65,1} & 71,1 & 96,5 \\
\hline & \multicolumn{4}{|l|}{$150 \%$} \\
\hline & \multicolumn{4}{|l|}{$100 \%$} \\
\hline & $50 \%$ & $65,1 \%$ & $71,1 \%$ & $96,5 \%$ \\
\hline & $0 \%$ & Pra Penelitian & Siklus I & Siklus II \\
\hline
\end{tabular}

Gambar 7. Persentase nilai rata-rata siswa

Dari tabel 14 dan gambar 7 di atas, nilai rata-rata siswa pada pra penelitian sebesar 65,1 dan pada siklus I sebesar 71,1 sehingga terjadi peningkatan dan pada akhir siklus II sebesar 96,5 berkategori ST. Sedangkan nilai klasikal hasil belajar siswa pada pra siklus sebesar 23,0 $\%$ dan meningkat pada siklus I sebesar 53,8 \% II. Pada akhir siklus II pun terjadi peningkatan sebesar $88,4 \%$ dan berkategorikan SB. Sehingga, dapat disimpulkan bahwa penelitian ini berhasil karena terjadi peningkatan nilai hasil belajar siswa dari siklus I dan siklus II dan model pembelajaran kooperatif tipe STAD berbantuan media kantong bilangan efektif diterapkan di kelas III pada mata pelajaran Matematika SD Negeri 96 Campurejo. 


\section{a) Refleksi siklus II}

Berdasarkan pelaksanaan tindakan pada siklus II, peneliti melakukan refleksi: 1) Saat akan berkumpul dengan kelompoknya masing-masing, siswa sudah bisa diatur dengan baik, 2) Saat berkumpul dengan teman kelompoknya, siswa sudah membaur dengan teman kelompoknya dan saling bekerja sama, 3) Saat pengerjaan LKS, tidak ada lagi siswa yang kebingungan, 4) Saat berkumpul dengan teman kelompoknya, siswa sudah kompak, dan 5) Siswa sudah tidak lagi dibantu oleh guru dalam mengerjakan kuis menggunakan media di depan kelas.

Hasil belajar siswa secara klasikal pada siklus II sebesar 88,4 \% dan berada pada kategori (Sangat Baik). Jika nilai hasil belajar siswa secara klasikal pada siklus II lebih tinggi dibandingkan siklus sebelumnya dengan indikator keberhasilan $\geq 70$. maka sudah memenuhi indikator keberhasilan, berarti penelitian ini dapat dihentikan.

\section{Pembahasan}

Berdasarkan penelitian di atas, menunjukkan bahwa setelah pemberian tindakan selama dua siklus dengan menggunakan model pembelajaran kooperatif tipe STAD berbantuan media kantong bilangan untuk meningkatkan hasil belajar matematika siswa mengalami peningkatan. Penerapan model pembelajaran kooperatif tipe STAD berbantuan media kantong bilangan efektif meningkatkan hasil belajar siswa karena pada dasarnya model pembelajaran kooperatif tipe STAD meningkatkan dan mengembangkan keterampilan berfikir peserta didik serta kerja kelompok, menciptakan hubungan positif antar peserta didik diantara perbedaan suku, ras, dan kemampuan peserta didik. Hal ini sejalan dengan penelitian yang dilakukan oleh (Zakaria, 2010) dimana terbukti menerapkan metode pembelajaran kooperatif tipe STAD meningkatkan hasil belajar dan sikap siswa dalam belajar Matematika.

Sedangkan kantong bilangan merupakan media 3 dimensi yang memberikan gambaran proses konkret dalam pembelajaran, gambaran nyata ini diperoleh dari pengoperasian yang dilakukan menggunakan kantong-kantong dan sedotan yang dijadikan bentuk konkret dari simbol matematika. Dengan gambaran nyata dari media kantong bilangan mampu mempengaruhi kondisi siswa sehingga dapat meningkatkan motivasi anak dan pemahaman anak serta hasil belajar siswa (Heruman, 2012).

Selama proses pembelajaran, guru membentuk kelompok-kelompok kecil dengan jumlah anggota tiap kelompok 4-5 orang secara heterogen. Semua siswa akan terlibat langsung dalam proses pembelajaran. Oleh karenanya belajar mengajar dengan model pembelajaran koperatif tipe STADberbantuan media kantong bilangan akan memberikan pengaruh terhadap peningkatan aktivitas belajar siswa. Hal ini sejalan dengan hasil penelitian yang pernah dilakukan oleh (Nina, 2012) tentang penerapan model pembelajaran kooperatif tipe STAD dapat meningkatkan aktivitas dan hasil belajar siswa dalam pembelajaran PKN.

Menurut (Martianty, 2011) Sikap positif siswa terhadap pembelajaran pengurangan bilangan dengan teknik meminjam melalui media kantong bilanganakan membuat siswa antusias untuk belajar. Keadaan seperti ini sebenarnyadapat menjadi modal untuk menciptakan suasana belajar yang efektif agar dapatmeningkatkan hasil belajar siswa.

Penghargaan prestasi tim dengan cara guru memeriksa hasil kerja siswa dan diberikan angka rentang 0-100 setelah pelaksanaan kuis. Guru memberikan penghargaan atas keberhasilan telah menyelesaikan kuis dengan benar dan memperoleh nilai tertinggi. Penghargaan tidak harus berupa materi. Penghargaan juga dapat diberikan dalam bentuk nilai tambahan atau hal non materi lain. Penelitian yang relevan dengan penelitian ini adalah 
penelitian yang pernah dilakukan oleh (Esminarto, 2016) tentang implementasi model STAD meningkatkan hasil belajar siswa.

Hasil belajar siswa pada pelajaran matematika dapat dilihat sebelum penerapan model pembelajaran kooperatif tipe STAD berbantuan media kantong bilangan nilai rata-rata siswa sebesar 65,1. Siswa yang mencapai KKM sebanyak 6 siswa dengan persentase 23,0 \% dan siswa yang belum mencapai KKM sebanyak 20 siswa dengan persentase 76,9\%.

Hasil belajar siswa setelah penerapan model pembelajaran kooperatif tipe STAD berbantuan media kantong bilangan pada siklus I nilai rata-rata siswa sebesar 71,1. Siswa yang mencapai KKM sebanyak 14 siswa dengan persentase 53,8 \%. Sedangkan siswa yang belum mencapai KKM sebanyak 12 siswa dengan persentase 46,1\%. Pada siklus I ini nilai rata-rata siswa sudah meningkat, namun penelitian ini belum memenuhi indikator keberhasilan yaitu ketuntasan belajar klasikal siswa sebesar $70 \%$ dan penelitian ini dilanjutkan pada siklus II. Hal ini sejalan dengan pendapat (Wardana, 2017) model pembelajaran kooperatif tipe STAD menekankan pada kerjasama kelompok. Dengan dilakukan kerja kelompok diharapkan akan melatih siswa untuk mengungkapkan pendapat dan meningkatkan pemahaman konsep secara bersama, serta dengan terjalinnya kerja sama kelompok dengan baik maka siswa dapat lebih memahami konsep yang ada dengan bantuan temannya. Keunggulan pembelajaran koopertatif tipe STAD terletak pada langkah-langkah pembelajaran yang diterapkan.

Selanjutnya pada siklus II terjadi peningkatan hasil belajar siswa menggunakan model pembelajaran kooperatif tipe STAD berbantuan media kantong bilangan dimana nilai rata-rata siswa sebesar 96,5. Siswa yang mencapai KKM sebanyak 23 siswa dengan persentase 88,4 \% dan siswa yang belum mencapai KKM hanya 3 siswa dengan persentase $11,5 \%$. Pada siklus II ini, nilai rata-rata siswa dan ketuntasan belajar klasikal siswa sudah meningkat sesuai dengan indikator keberhasilan. Sehingga penelitian ini tidak dilanjutkan pada siklus berikutnya. Hal ini sesuai pendapat (Sudjana,2017) hasil belajar adalah kemampuan yang dimiliki siswa setelah menerima pengalaman belajar.

Hasil observasi aktivitas siswa pada siklus I dengan model pembelajaran kooperatif tipe STAD berbantuan media kantong bilangan mendapat rata-rata capaian $64, \%$ dengan kategori (Rendah) dan terjadi peningkatan pada siklus II sebesar 75\% dengan kategori (Tinggi). Selain hasil observasi aktivitas siswa, hasil obervasi aktivitas guru pada siklus I mendapat rata-rata capaian sebesar 70\% dengan kategori (Baik) dan terjadi peningkatan pada siklus II sebesar 91\% dengan kategori (Sangat Baik). Penelitian yang relevan dengan penelitian ini adalah penelitian yang pernah dilakukan oleh (Nurachmad, 2015) tentang penerapan model pembelajaran koperatif tipe STAD dalam meningkatkan hasil belajar siswa.Kesimpulan

Berdasarkan hasil penelitian, diperoleh informasi bahwa dalam melakukan operasi hitung bilangan bulat, siswa sangat mungkin melakukan kesalahan prosedural dan kesalahan konsep. Bentuk kesalahan prosedural yang dilakukan siswa yaitu: (1) Kurang teliti dalam menuliskan ulang soal, (2) Kurang Teliti dalam menghitung hasil penjumlahan dan pengurangan, (3) Lupa menuliskan tanda negatif pada hasil penjumlahan dan pengurangan, (4) Kesalahan urutan dalam melakukan operasi penjumlahan dan pengurangan, dan (5) Tidak Menuliskan jawaban secara lengkap. Sedangkan ada 3 bentuk kesalahan konsep yang dilakukan siswa yaitu: (1) Kesalahan dalam menjumlahkan bilangan negatif, (2) Kesalahan dalam pengurangan bilangan bulat sejenis $(\mathrm{a}-\mathrm{b}$ untuk $\mathrm{a}<\mathrm{b}$ atau $(-\mathrm{a})-(-\mathrm{b}))$, dan (3) Kesalahan dalam melakukan operasi lambang " - " dengan bilangan negatif.

3 jenis kesalahan yang dihasilkan dapat digunakan sebagai acuan untuk memperoleh jenis pembelajaran yang mampu menminimalkan kesalahan siswa. Selanjutnya, sebagai penelitian lanjutan kami mencoba menggali proses berfikir siswa yang menyebabkan mereka melakukan kesalahan. Kami menduga hal ini berkaitan dengan terjadinya interferensi dalam struktur 
kognitif siswa, adanya ketidak koneksian antara antar konsep, adanya miskonsepsi, dan adanya ketidaksadaran siswa dari kebiasaan dalam menyelesaikan.

\section{E. Kesimpulan}

Berdasarkan hasil penelitian yang telah dilaksanakan, dapat disimpulkan sebagai berikut: Hasil belajar siswa pada pelajaran matematika sebelum penerapan model pembelajaran kooperatif tipe STAD berbantuan media kantong bilangan nilai rata-rata siswa sebesar 65,1. Siswa yang mencapai KKM sebanyak 6 siswa dengan persentase 23,0 \% dan siswa yang belum mencapai KKM sebanyak 20 siswa dengan persentase 76,9 \%. Hasil belajar siswa setelah penerapan model pembelajaran kooperatif tipe STAD berbantuan media kantong bilangannilai rata-rata siswa sebesar 71,1. Siswa yang mencapai KKM sebanyak 14 siswa dengan persentase $53,8 \%$. Sedangkan siswa yang belum mencapai KKM sebanyak 12 siswa dengan persentase $46,1 \%$. Pada siklus II terjadi peningkatan hasil belajar siswa dengan menerapkan model pembelajaran kooperatif tipe STAD berbantuan media kantong bilangan dimana nilai rata-rata siswa sebesar 96,5. Siswa yang mencapai KKM sebanyak 23 siswa dengan persentase 88,4 \% dan siswa yang belum mencapai KKM hanya 3 siswa dengan persentase 11,5\%.Hasil tersebut juga menunjukkan bahwa hasil belajar siswa melalui penerapan model pembelajaran kooperatif tipe STADberbantuan media kantong bilangan telah efektif diterapkan dalam penelitian ini.

\section{DAFTAR PUSTAKA}

Agung. 2010. Metodelogi Penelitian Pendidikan. Bali: Universitas Ganesha

Arikunto. 2016. Penelitian Tindakan Kelas. Jakarta: Bumi Aksara.

Esminarto. 2016. Implementasi model STAD dalam meningkatkan hasil belajar siswa. Kediri: Unublitar.

Heruman. 2012. Model Pembelajaran Matematika di Sekolah Dasar. Bandung: Remaja Rosdakarya.

Martianty. 2011. Meningkatan keterampilan siswa pada pengurangan bilangan cacah dengan teknik meminjam melalui media kantong bilangan di kelas ii sdn pauwo kecamatan kabila kabupaten bone bolango.

Nina. 2012. Meningkatkan Aktivitas dan Hasil Belajar Siswa dalam Pembelajaran PKN pada Materi Persamaan Kedudukan Warga Negara dengan Model Pemblajaran Student TeamsAchievement Division di Kelas X-II SMA PGRI 4 Banjarmasin.

Nurachmad. 2015. Penerapan Model Pembelajaran Kooperatif Tipe STAD (Student Teams Achievement Division) Untuk Meningkatkan Hasil Belajar Siswa Kelas IV Sdn Marmoyo Jombang.

Purwanto. 2011. Belajar dan Pembelajaran Sekolah Dasar. Bandung: UPI Press.

Qomariyah. 2019. Penerapan Media Kantong Bilangan Untuk Meningkatkan Hasil Belajar Matematika Siswa. Probolinggo: Universitas Panca Marga. 
Runtukahu. 2014. Pembelajaran Matematika Dasar Bagi Anak Nerkesulitan Belajar. Yogyakarta: Ar-Ruzz Media.

Rusman. 2012. Model-model Pembelajaran Mengembangkan Profesionalisme Guru. Jakarta: Grafindo Persada.

Sudjana. 2017. Penilaian Hasil Belajar Proses Belajar Mengajar. Bandung: Remaja Rosdakarya.

Wardana. 2017. Penerapan Model Pembelajaran Kooperatif Tipe Student Team Achivement Division (STAD) untuk Meningkatkan Hasil Belajar Siswa Kelas XI IPA Avogadro SMA Negeri 2 Pangkajene (Studi pada Materi Asam Basa). Semarang: Universitas PGRI Semarang.

Zakaria. 2010. The Effects of Cooperative Learning on Students Mathematics Achievement and Attitude towards Mathematics. 